\title{
INFLUENCE OF SUBSTRATE AND SPECIES ARRANGEMENT OF CULTIVATED GRASSES ON THE EFFICIENCY OF HORIZONTAL SUBSURFACE FLOW CONSTRUCTED WETLANDS
}

\author{
Claudety B. Saraiva ${ }^{1 *}$, Antonio T. Matos ${ }^{2}$, Mateus P. Matos ${ }^{3}$, Suymara T. Miranda ${ }^{4}$
}

${ }^{1 *}$ Corresponding author. Empresa de Pesquisa Agropecuária de Minas Gerais- EPAMIG/ Juiz de Fora - MG, Brasil.

E-mail: claudety@epamig.br

\section{KEYWORDS}

wastewater, elephant grass, Tifton 85

bermudagrass, plants, porosity.

\begin{abstract}
We aimed to evaluate the efficiency of six different horizontal subsurface flow constructed wetlands (HSSF-CWs), with different substrates (gravel and crushed PET bottles), which also varied in relation to the presence and arrangement of plant species (elephant grass and Tifton 85 bermudagrass) in the removal of pollutants from a bulk milk cooling tank (MTWW). Each bed was fed at a flow rate of $0.18 \mathrm{~m}^{3} \mathrm{~d}^{-1}$ and average organic load rate (OLR) of $318 \mathrm{~kg} \mathrm{ha}^{-1} \mathrm{~d}^{-1}$ of $\mathrm{BOD}_{5}$, with hydraulic detention time (HRT) of 1.84 days in the gravel-filled HSSF-CWs $\left(\mathrm{CW}_{\mathrm{S}}-\mathrm{G}\right)$ and 2.97 days in the PET-filled HSSF-CWs (CWs-P). The CWs-P were as efficient as the CWs-G in the removal of $\mathrm{BOD}_{5}$, COD, Total-P, and K-Total, being in some cases even more effective (turbidity, TS, TSS and Na). The gravel, on the other hand, provided greater removals of Total-N from the MTWW. In the non-cultivated CWs and those cultivated with elephant grass, in its first half and Tifton 85 grass in its second half, there were higher average efficiencies in COD and TSS removal sand, in the latter, the highest average removal of Total-N.
\end{abstract}

\section{INTRODUCTION}

The bulk milk cooling tank, also known as the expansion tank, is an equipment that receives and stores milk in bulk (without the use of brass) and provides its direct cooling (Melo \& Reis, 2007), as required by law. These tanks, located mostly in rural areas, are subject to the same sanitation operations that occur in the dairy industry, consuming large volumes of water, chemicals and, consequently, generating an effluent with polluting potential. As aggravating this effluent has been discarded without any previous treatment in water bodies. Therefore, the study of ways of treating this wastewater has become necessary.

In order to treat wastewater generated in a rural area that is difficult to access and does not have operators, it is necessary to use low cost installation and operation techniques and among these constructed wetlands systems stand out.

The Constructed Wetlands Systems $\left(\mathrm{CW}_{\mathrm{S}}\right)$ can be a promising technical alternative, since it is a simple, low cost and easy operation and maintenance technology for the treatment of a wide variety of wastewater, such as domestic (Avelar et al., 2015), of dairy products (Matos et al., 2012; Mendonça et al., 2015), of swine farming (Sarmento et al., 2012; Fia et al., 2015), of textile industry (Saeed \& Sun, 2013) and drugs industry (Zhang et al., 2014).

The CWs can be defined as reactors filled with porous materials that provide hydraulic conductivity and support for microbial growth and plant species. The system formed by the filtering substrate, the adhered biofilm and the plants, favors the degradation of part of the organic matter in the solution, the removal of sediment and suspended solids, of nutrients and other contaminants, through physical, chemical and biological processes, providing the debugging of wastewater (Prata et al., 2013). The removal efficiencies of the CWs depend on the choice of the type of liquid inlet and outlet configurations, feed rate, applied loads, environmental conditions, type of substrate, and the plant species used (Kantawanichkul \& Wannasri, 2013; Wang et al., 2014a).

According to Dordio \& Carvalho (2013), gravel, sand, gravel and soil are the materials most used as means of plant support, microorganism fixation and solid

\footnotetext{
${ }^{2}$ Universidade Federal de Minas Gerais/ Belo Horizonte - MG, Brasil.

${ }^{3}$ Universidade Federal de Lavras/ Lavras - MG, Brasil.

${ }^{4}$ Engenheira Agrícola e Ambiental/ Viçosa - MG, Brasil.

Received in: 8-21-2017

Accepted in: 4-8-2018
} 
filtration. On the other hand, the placement of these filter media provides a fast clogging either by the size of their pores or by possible wear over the operating time (Pedescoll et al., 2009). Thus, the use of materials that are inert and easy to acquire, can become an interesting solution in terms of the associated costs (purchase and replacement). In this context, PET bottles (polyethylene terephthalate), whose destination has increasingly become an environmental liability, requiring recycling and reuse, have the potential to serve as an alternative means of support for HSSF-CWs. On the other hand, the availability of scientific articles related to their use is still little, therefor, requiring more studies to evaluate, in practice, the performance of CWs filled with this material.

As for plant species, several plants have already been used, from macrophytes present in aquatic environments, ornamental flowers and forage grasses (Chang et al., 2012; Zacarkim et al., 2014; Borges et al., 2015; Calheiros et al., 2015). The last ones are notable for their high extractive capacity, easy adaptation and rapid growth, such as the elephant grass (Pennisetum purpureum Schum) and Tifton 85 (Cynodon ssp.). As plant species have different nutrient requirements and environmental development conditions, intercropping can be another important variable to increase the efficiency of these systems. To make the technique even more attractive, grasses of interest were evaluated in the dairy chain, since they can be supplied for feeding dairy cattle.

In the light of the above, the objective of this study was to evaluate the extractive capacity of elephant grass, Napier cv. (Pennisetum purpureum Schum) and Tifton 85 grass (Cynodon spp), when treated in different ways in

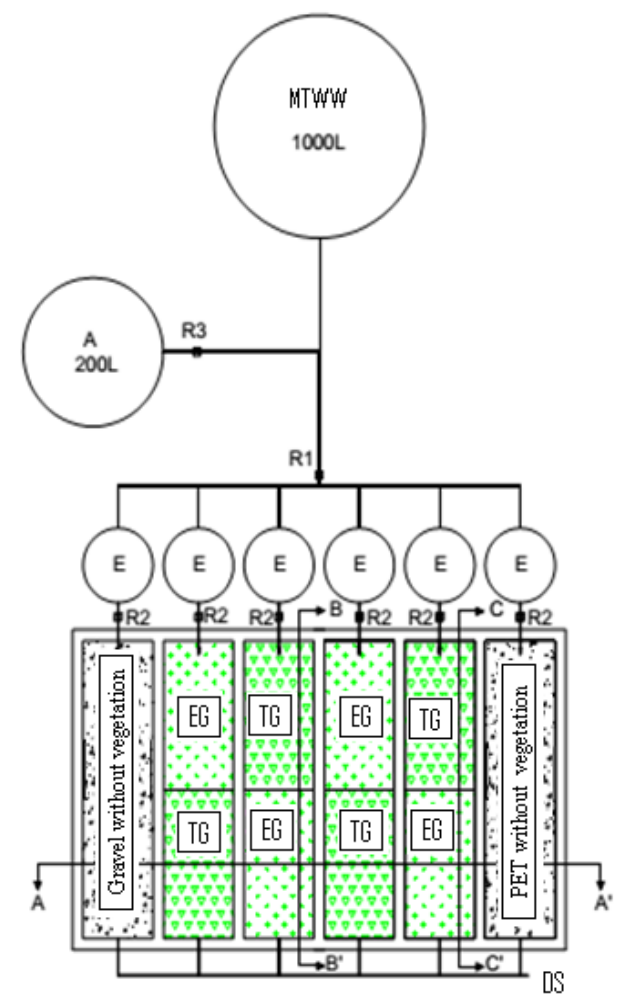

HSSF-CWs filled with different types of substrates, in the treatment of a community bulk milk cooling tank (MTWW).

\section{MATERIAL AND METHODS}

In order to carry out this study, gross wastewater generated in the process of cleaning the community bulk milk cooling tank was used, located in the municipality of Silveirânia-MG, located in Zona da Mata Mineira, where the pilot scale experiment was implemented and conducted. This wastewater is composed of milk residues, detergent-sanitizers, waste from bovine livestock (cleaning of brass) and sand.

The experimental infrastructure consisted of six HSSF- $\mathrm{CW}_{\mathrm{s}}$, in the dimensions of $0.6 \mathrm{~m}$ height $\mathrm{x} 1.0 \mathrm{~m}$ width $\times 2.5 \mathrm{~m}$ in length, positioned on the ground, having the bottom (level) and the sides waterproofed with $0.5 \mathrm{~mm}$ thick PVC tarpaulin, mounted parallel and delimited by masonry walls.

The distribution of the affluent was given at the central point at the entrance of each $\mathrm{HSSF}-\mathrm{CW}_{\mathrm{S}}$ through a $1 / 2$-inch plastic tap where the flow control was made. The

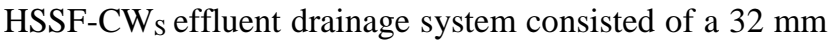
diameter PVC pipe, perforated, installed in the bottom of the exit zone. The height of the water level was $0.35 \mathrm{~m}$, in both types of substrate (gravel \# 0 and crushed PET bottles).

In Figure 1, a sketch is presented with the general scheme of the experiment.

FIGURE 1. Sketch detailing the general scheme of the experiment.

\author{
Legend \\ MTWW = Bulk milk wastewater \\ tank \\ $\mathrm{A}=$ Pure water tank \\ $\mathrm{E}=$ Equalization tank \\ $\mathrm{R} 1$ = General valve \\ $\mathrm{R} 2$ = Sewer inlet valve in the $\mathrm{CW}_{5}$ \\ R3 = Pure water inlet valve \\ DS= Drainage system \\ $\mathrm{T} G=\mathrm{Tifton}-85$ grass \\ $E G=$ Elephantgr ass
}


The HSSF-CWs 1,2 and $3\left(\mathrm{CW}_{\mathrm{S}}-\mathrm{GWV}, \mathrm{CW}_{\mathrm{S}}-\mathrm{GET}\right.$ and $\left.\mathrm{CW}_{\mathrm{S}}-\mathrm{GTE}\right)$ were filled with gravel \# $0\left(\mathrm{D}_{60}=9.1 \mathrm{~mm}\right.$, coefficient of uniformity $-\mathrm{CU} \mathrm{D}_{60} / \mathrm{D}_{10}=3.1$ and initial void volume, $\mathrm{n}=0.398 \mathrm{~m}^{3} \mathrm{~m}^{-3}$ ), while the HSSF-CWs 4,5 and $6\left(\mathrm{CW}_{\mathrm{S}}\right.$-PET, $\mathrm{CW}_{\mathrm{S}}$-PTE and $\left.\mathrm{CWs}-\mathrm{PWV}\right)$ were filled with PET bottles $(250$ and $500 \mathrm{~mL})\left(\mathrm{n}=0.642 \mathrm{~m}^{3} \mathrm{~m}^{-3}\right)$. Figure 2 shows the equipment used to knead the PET bottles and the material ready to be used as a substrate in the HSSF-CWs.

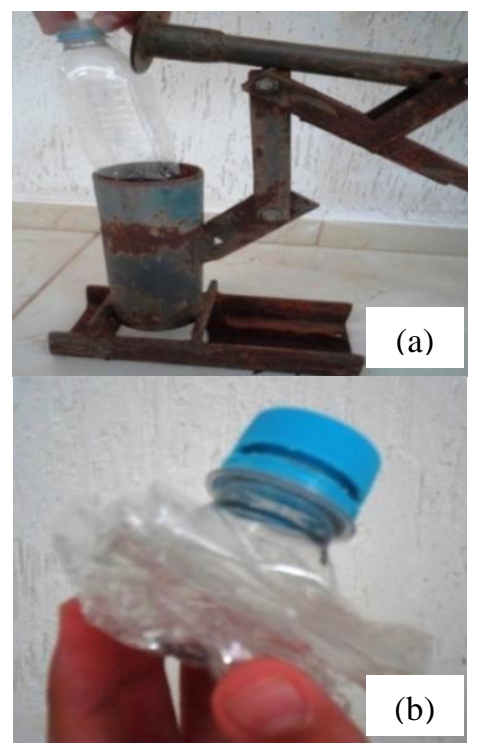

FIGURE 2. Equipment used to knead the bottles (a), bottle used as substrate (b).
To determine the porosity (n) of the medium consisting of the kneaded PET bottles, a glass vessel (aquarium-like) of known volume (Vr) was used, which was filled with the material, where, then, was added water, with the aid of a test tube, until filling the entire porous space of the material. With the required volume of water $(\mathrm{Vw})$ to fill the container, the void ratio or porosity of the substrate was determined using [eq. (1)], and the value obtained was $64.22 \%$. In relation to the gravel porosity \# 0 , the value obtained by Ferres et al. (2017).

$$
\mathbf{n}=\mathrm{Vw}_{\mathbf{w}} / \mathrm{V} \mathbf{r}
$$

In the HSSF-CWs where the substrate used was gravel \# 0, the material depth was $0.45 \mathrm{~m}$. In the HSSFCWs whose substrate was composed of crushed PET bottles, the depth of the layer of this material was $0.35 \mathrm{~m}$, being placed above that layer, another of $0.10 \mathrm{~m}$ of gravel \# 3, to avoid that the bottles floated when the CWs-P were fed with MTWW. As the water level was maintained at $0.10 \mathrm{~m}$ below the surface of both HSSF-CWs (gravel\# 0 and crushed PET bottles + gravel layer \# 3), it is important to point out that even with this change in the disposal of the filling material, the waste water flow in the HSSF-CWs filled with PET bottles remained only by the layer of this material, so the wet height in both systems was $0.35 \mathrm{~m}$. In Figure 3, an overview of the six HSSF-CWs used in this study.

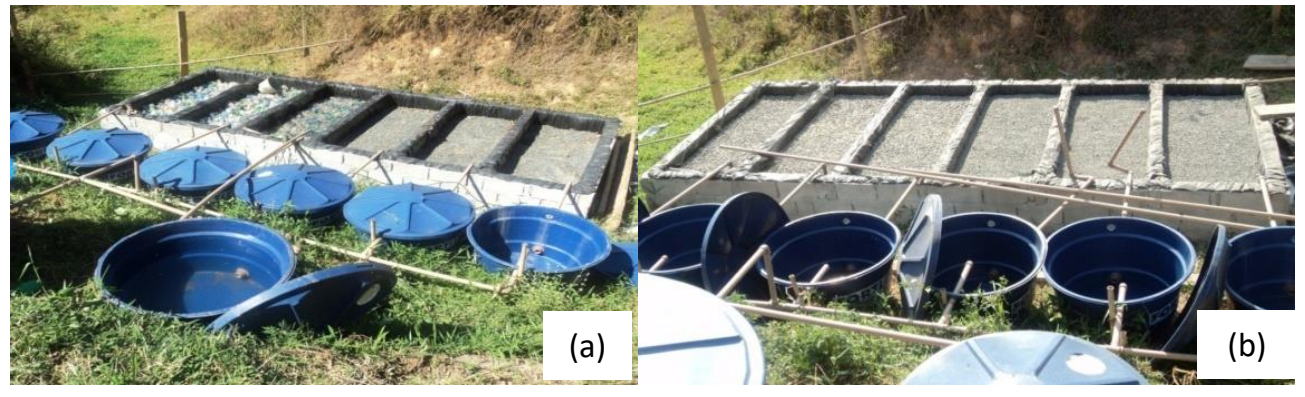

FIGURE 3. Overview of the six HSSF-CW , three filled with PET bottles; and three filled with gravel \# 0 (a) and after placement of the cover layer with gneissic gravel \# 3 (b).

In $\mathrm{CW}_{\mathrm{S}}-\mathrm{GET}$ (2) and $\mathrm{CW}_{\mathrm{S}}$-PET (4) elephant grass was cultivated in the first half and Tifton grass 85 in the second half. The $\mathrm{CW}_{\mathrm{S}}-\mathrm{GTE}$ (3) and $\mathrm{CW}_{\mathrm{S}}$-PTE (5), in turn, were planted in reverse arrangement of the plant species, with Tifton 85 grass in the first half and elephant grass in the second half. In these units, the planting of each plant species with density of 19 propagules per square meter was carried out. On the other hand, the $\mathrm{CW}_{\mathrm{S}}-\mathrm{GWV}(1)$ and $\mathrm{CW}_{\mathrm{S}}$-PWV (6) were kept uncultivated.

Each bed was fed with $0.18 \mathrm{~m}^{3} \mathrm{~d}^{-1}$ and average organic load (OLR) of $318 \mathrm{~kg} \mathrm{ha}^{-1} \mathrm{~d}^{-1}$ of $\mathrm{BOD}_{5}$, with hydraulic detention time of 1.84 days in the CWs filled with the gravel $\left(\mathrm{CW}_{\mathrm{S}} \mathrm{G}\right)$ and 2.97 days in the $\mathrm{CWs}$ with PET $\left(\mathrm{CW}_{\mathrm{S}}-\mathrm{P}\right)$.

Evaporation water losses $\left(\mathrm{CW}_{\mathrm{S}^{-}} \mathrm{GWV}\right.$ and $\mathrm{CW}_{\mathrm{S}^{-}}$ PWV) and evapotranspiration $\left(\mathrm{CW}_{\mathrm{S}}-\mathrm{GET}, \mathrm{CW}_{\mathrm{S}} \mathrm{GTE}\right.$, $\mathrm{CW}_{\mathrm{S}}$-PET and $\mathrm{CW}_{\mathrm{S}}$-PTE) were calculated based on the difference between the inflow and effluent flows in the systems.

In the calculation of the efficiency in the removal of pollutants / nutrients was considered the evaporation / evapotranspiration in each of the HSSF-CWs, as presented in [eq. (2)].

Where

$$
\mathrm{EF}=\frac{[(\mathrm{QAf} \cdot \mathrm{CAf})-(\mathrm{QAf}-\mathrm{Ev}) \cdot \mathrm{CEf})]}{(\mathrm{QAf} \cdot \mathrm{CAf})}
$$

\footnotetext{
$\mathrm{EF}=$ efficiency in removal of the pollutant (\%);

$\mathrm{C}_{\mathrm{Af}}=$ input concentration (variable unit);

$\mathrm{Q}_{\mathrm{Af}}=$ affluent flow $\left(\mathrm{m}^{3} \mathrm{~d}^{-1}\right)$;

$\mathrm{C}_{\mathrm{Ef}}=$ effluent concentration (variable unit);

$\mathrm{Ev}=$ evaporation / evapotranspiration in HSSF-CWs $\left(\mathrm{m}^{3} \mathrm{~d}^{-1}\right)$.
} 
To evaluate the performance of the systems, 12 samples of the wastewater and effluent from each HSSF$\mathrm{CW}_{\mathrm{S}}$ were carried out, measuring the electrical conductivity, turbidity and $\mathrm{pH}$ and quantifying the concentrations of $\mathrm{BOD}_{5}, \mathrm{COD}$, TSS, Total-N, Total-P, K and $\mathrm{Na}$. The experiment was monitored for 8.5 months.

The procedure of collection, preservation of samples and analyzes was carried out according to the recommendations of the Standard Methods for Examination of Water and Wastewater (APHA, 2012) and Matos (2015). The analyzes were carried out in the Laboratory of Water Quality (LWQ), Department of Agricultural Engineering of the Federal University of Viçosa (UFV).

The efficiencies in the removal of the studied variables were analyzed statistically in the $2 \times 3$ factorial scheme, a total of 6 treatments. The first factor, support material, with two levels (gravel \# 0 and crushed PET bottles) and the second factor, combination of cultivation, with three levels (without vegetation - WV, elephant grass and Tifton 85 - ET and Tifton 85 and elephant grass - TE). The type of design was randomized blocks (DRB) with the number of blocks for each variable as a function of the number of samples.

The means were submitted to Analysis of Variance (ANOVA, $\mathrm{p}=0.05$ ) and, when significant, the Tukey ( $\mathrm{p}=$ 0.05 ) among averages; having a significant interaction between the factors, the unfolding was performed. For verifications of the normality and homogeneity of variance assumptions, it was applied the Lilliefors Test and the Tests of Cochran Bartlett, respectively. For the data processing and the statistical analyzes, the software Assistat Beta Version7.7.

\section{RESULTS AND DISCUSSION}

The mean values and standard deviation of the surface application rate of $\mathrm{BOD}_{5}$, nitrogen (Total-N), phosphorus $(\mathrm{P})$, potassium $(\mathrm{K})$, sodium $(\mathrm{Na})$ and total solids (TS) were applied during the monitoring period were, respectively, $318 \mathrm{~kg} \mathrm{ha}^{-1} \mathrm{~d}^{-1}, 20 \mathrm{~kg} \mathrm{ha}^{-1} \mathrm{~d}^{-1}, 7.7 \mathrm{~kg} \mathrm{ha}^{-1} \mathrm{~d}^{-1}$, $7.1 \mathrm{~kg} \mathrm{ha}^{-1} \mathrm{~d}^{-1}, 8.2 \mathrm{~kg} \mathrm{ha}^{-1} \mathrm{~d}^{-1}$ and $421 \mathrm{~kg} \mathrm{ha}^{-1} \mathrm{~d}^{-1}$.

Table 1 shows the mean values of turbidity, $\mathrm{BOD}_{5}$, COD, TS, TSS, Total-N, Total-P, K and Na and effluent and their removal efficiencies in HSSF-CWs.

TABLE 1. Mean values of turbidity, EC, BOD 5, COD, TS, TSS, Total-N, Total-P, K and Na affluent and effluent and the efficiencies in their removals in HSSF-CWs.

\begin{tabular}{|c|c|c|c|c|c|c|c|c|c|}
\hline \multirow[t]{2}{*}{ Treatment } & \multicolumn{3}{|c|}{ Turbidity (UNT) } & \multicolumn{3}{|c|}{$\mathrm{EC}\left(\mu \mathrm{S} \mathrm{cm} \mathrm{cm}^{-1}\right)$} & \multicolumn{3}{|c|}{ pH } \\
\hline & Afl. & Efl. & Efi. (\%) & Afl. & Efl. & Efi. (\%) & Afl. & Efl. & Efi. $(\%)^{*}$ \\
\hline $\mathrm{CW}_{\mathrm{S}}-\mathrm{GWV}$ & 125 & 20 & 84 & 217 & 416 & -94 & 5.6 & 6.7 & ---- \\
\hline $\mathrm{CW}_{\mathrm{S}}-\mathrm{GET}$ & 125 & 30 & 78 & 217 & 414 & -79 & 5.6 & 6.7 & ---- \\
\hline $\mathrm{CW}_{\mathrm{S}}-\mathrm{GTE}$ & 125 & 25 & 81 & 217 & 419 & -98 & 5.6 & 6.7 & ---- \\
\hline $\mathrm{CW}_{\mathrm{S}}-\mathrm{PET}$ & 125 & 11 & 91 & 217 & 272 & -17 & 5.6 & 6.3 & ---- \\
\hline $\mathrm{CW}_{\mathrm{S}}-\mathrm{PTE}$ & 125 & 16 & 87 & 217 & 296 & -37 & 5.6 & 6.2 & ---- \\
\hline $\mathrm{CW}_{\mathrm{S}}-\mathrm{PWV}$ & 125 & 11 & 91 & 217 & 298 & -40 & 5.6 & 6.6 & ---- \\
\hline \multirow[t]{2}{*}{ Treatment } & \multicolumn{3}{|c|}{$\mathrm{TS}\left(\mathrm{mg} \mathrm{L}^{-1}\right)$} & \multicolumn{3}{|c|}{ TSS $\left(\mathrm{mg} \mathrm{L}^{-1}\right)$} & \multicolumn{3}{|c|}{ BOD $_{5}\left(\mathrm{mg} \mathrm{L}^{-1}\right)$} \\
\hline & Afl. & Efl. & Efi. (\%) & Afl. & Efl. & Efi. (\%) & Afl. & Efl. & Efi. (\%) \\
\hline $\mathrm{CW}_{\mathrm{S}}-\mathrm{GWV}$ & 570 & 250 & 58 & 201 & 15 & 91 & 403 & 63 & 87 \\
\hline $\mathrm{CW}_{\mathrm{S}}-\mathrm{GET}$ & 570 & 259 & 57 & 201 & 26 & 90 & 403 & 70 & 87 \\
\hline $\mathrm{CW}_{\mathrm{S}}-\mathrm{GTE}$ & 570 & 287 & 52 & 201 & 38 & 82 & 403 & 71 & 85 \\
\hline $\mathrm{CW}_{\mathrm{S}}-\mathrm{PET}$ & 570 & 183 & 70 & 201 & 9 & 96 & 403 & 60 & 87 \\
\hline $\mathrm{CW}_{\mathrm{S}} \mathrm{PTE}$ & 570 & 200 & 67 & 201 & 19 & 91 & 403 & 85 & 82 \\
\hline $\mathrm{CW}_{\mathrm{S}}-\mathrm{PWV}$ & 570 & 186 & 69 & 201 & 10 & 94 & 403 & 65 & 87 \\
\hline \multirow[t]{2}{*}{ Treatment } & \multicolumn{3}{|c|}{ COD $\left(\mathrm{mg} \mathrm{L}^{-1}\right)$} & \multicolumn{3}{|c|}{ Total-N (mg L $\left.{ }^{-1}\right)$} & \multicolumn{3}{|c|}{ Total-P $\left(\mathrm{mg} \mathrm{L}^{-1}\right)$} \\
\hline & Afl. & Efl. & Efi. (\%) & Afl. & Efl. & Efi. (\%) & Afl. & Efl. & Efi. (\%) \\
\hline $\mathrm{CW}_{\mathrm{S}}-\mathrm{GWV}$ & 702 & 64 & 93 & 26 & 20 & 30 & 10 & 9 & 20 \\
\hline $\mathrm{CW}_{\mathrm{S}}-\mathrm{GET}$ & 702 & 74 & 91 & 26 & 15 & 50 & 10 & 8 & 27 \\
\hline $\mathrm{CW}_{\mathrm{S}}-\mathrm{GTE}$ & 702 & 108 & 88 & 26 & 18 & 38 & 10 & 9 & 22 \\
\hline $\mathrm{CW}_{\mathrm{S}}-\mathrm{PET}$ & 702 & 79 & 92 & 26 & 17 & 43 & 10 & 8 & 29 \\
\hline $\mathrm{CW}_{\mathrm{S}}-\mathrm{PTE}$ & 702 & 133 & 86 & 26 & 18 & 37 & 10 & 9 & 23 \\
\hline $\mathrm{CW}_{\mathrm{S}}-\mathrm{PWV}$ & 702 & 83 & 92 & 26 & 23 & 21 & 10 & 8 & 27 \\
\hline \multirow[t]{2}{*}{ Treatment } & \multicolumn{3}{|c|}{ K-Total $\left(\mathrm{mg} \mathrm{L}^{-1}\right)$} & \multicolumn{6}{|c|}{ Na-Total $\left(\mathrm{mg} \mathrm{L}^{-1}\right)$} \\
\hline & \multicolumn{2}{|c|}{ Afl. } & Efl. & \multicolumn{2}{|c|}{ Efi. (\%) } & Afl. & \multicolumn{2}{|c|}{ Efi. (\%) } & \\
\hline $\mathrm{CW}_{\mathrm{S}}-\mathrm{GWV}$ & \multicolumn{2}{|c|}{11} & 10 & \multicolumn{2}{|c|}{15} & 12 & \multicolumn{2}{|c|}{6} & \\
\hline $\mathrm{CW}_{\mathrm{S}}-\mathrm{GET}$ & \multicolumn{2}{|c|}{11} & 9 & \multicolumn{2}{|c|}{23} & 12 & 15 & -14 & \\
\hline $\mathrm{CW}_{\mathrm{S}}-\mathrm{GTE}$ & \multicolumn{2}{|c|}{11} & 11 & \multicolumn{2}{|c|}{11} & 12 & \multicolumn{2}{|c|}{-12} & \\
\hline $\mathrm{CW}_{\mathrm{S}}-\mathrm{PET}$ & \multicolumn{2}{|c|}{11} & 10 & & & 12 & 13 & & \\
\hline $\mathrm{CW}_{\mathrm{S}}-\mathrm{PTE}$ & & & 10 & & & 12 & 12 & & \\
\hline $\mathrm{CW}_{\mathrm{S}}-\mathrm{PWV}$ & & & 11 & & & 12 & 13 & & \\
\hline
\end{tabular}

In which, Afl. is the measure in the affluent, Efl. in the effluent (after treatment), and Efi. (\%), the percentage of removal. 
Variations in the removal efficiencies of the analyzed variables, over the period of experimental monitoring, are presented in Figure 4.
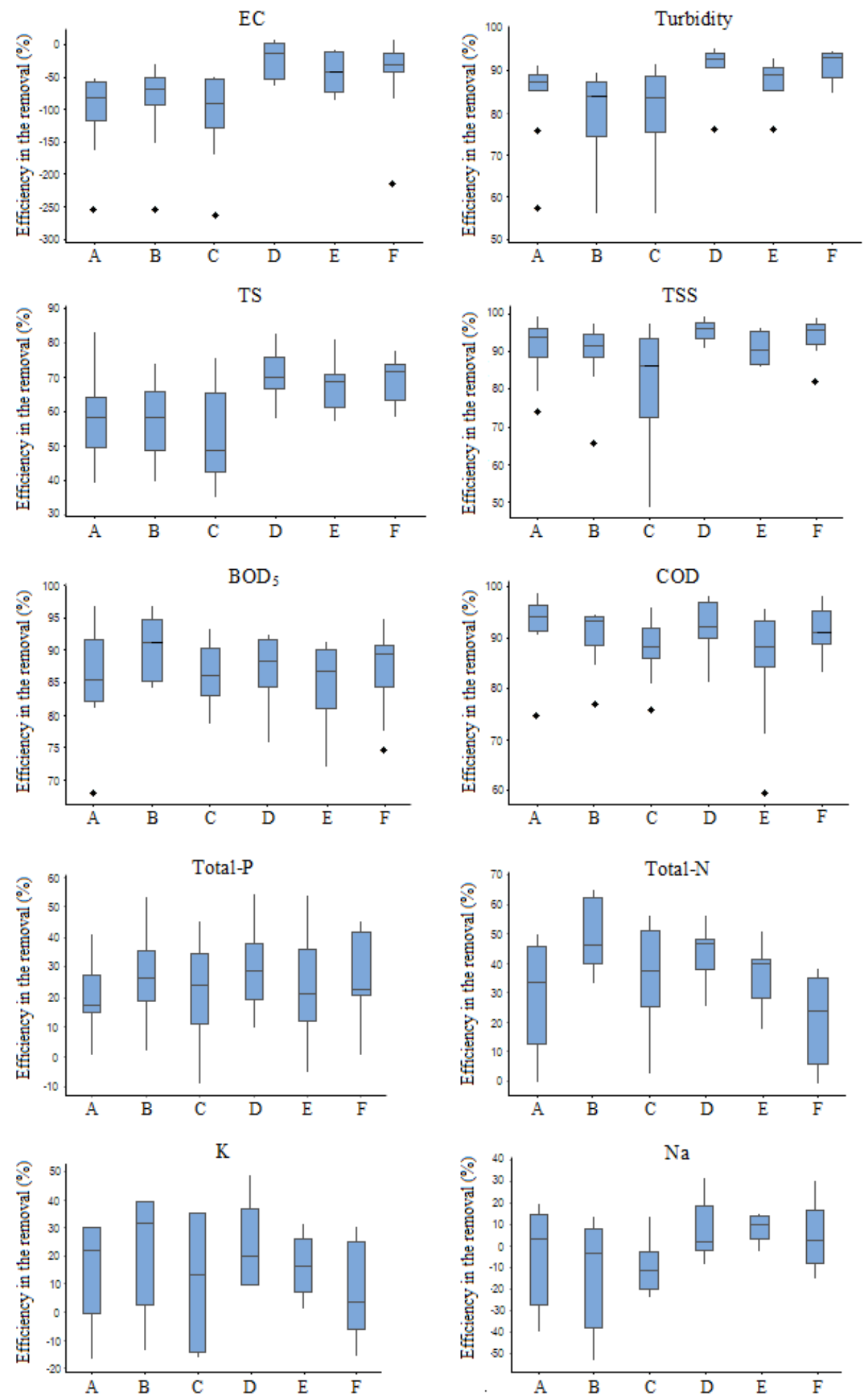

Where, A: CWs-GWV; B: CWs- GET; C: CWs-GTE; D: CWs-PET; E: CWs-PTE; and F: CWs-PWV.

FIGURE 4. Variation of efficiency in the removal of EC, Turbidity, TS, TSS, BOD 5 , COD, Total-P, Total-N, K and Na, over the period of experimental monitoring.

The results of the statistical analysis of the mean efficiencies in the removal of the studied variables related to the type of support material and the combination of culture in the HSSF-CW are presented in Table 2. 
TABLE 2. Average efficiency in the removal of $\mathrm{BOD}_{5}, \mathrm{COD}$, turbidity, EC, TS, TSS, Total-P, Total-N, K and Na in the different material supports and crop combination.

\begin{tabular}{|c|c|c|c|c|c|c|}
\hline *Factor & Factor level & & Efficienc & removal( & & \\
\hline & & EC & Turbidity & TS & TSS & COD \\
\hline Substrate & $\mathbf{G}$ & $-92 b$ & $81 b$ & $56 b$ & $88 b$ & $91 \mathrm{a}$ \\
\hline & $\mathbf{P}$ & $-32.0 \mathrm{a}$ & $90 \mathrm{a}$ & $69 \mathrm{a}$ & $94 a$ & $90 \mathrm{a}$ \\
\hline & $\mathbf{W V}$ & $-67.5 \mathrm{a}$ & $88 \mathrm{a}$ & $63 a$ & $93 \mathrm{a}$ & $92 \mathrm{a}$ \\
\hline Combination of cultivation & ET & $-57.0 \mathrm{a}$ & $85 \mathrm{a}$ & $64 \mathrm{a}$ & $93 a$ & $91 \mathrm{a}$ \\
\hline & TE & $-63.0 \mathrm{a}$ & $84 a$ & $60 \mathrm{~b}$ & $87 \mathrm{~b}$ & $86 b$ \\
\hline & & BOD5 & Total-P & Total-N & $\mathbf{K}$ & $\mathbf{N a}$ \\
\hline Substrate & $\mathbf{G}$ & $86 a$ & $23 \mathrm{a}$ & $39 a$ & $16 \mathrm{a}$ & $-6 b$ \\
\hline suostrate & $\mathbf{P}$ & $85 a$ & $26 \mathrm{a}$ & $34 b$ & $15 \mathrm{a}$ & $4 \mathrm{a}$ \\
\hline & $\mathbf{W V}$ & $87 \mathrm{a}$ & $24 \mathrm{a}$ & $26 \mathrm{c}$ & $11 \mathrm{a}$ & $6 a$ \\
\hline Combination of cultivation & ET & $87 \mathrm{a}$ & $28 \mathrm{a}$ & $47 \mathrm{a}$ & $23 a$ & $-3 a$ \\
\hline & TE & $84 a$ & $23 \mathrm{a}$ & $38 b$ & $14 \mathrm{a}$ & $-8 \mathrm{a}$ \\
\hline
\end{tabular}

(ET) (cultivated in the first half with elephant grass and in the second half with Tifton grass 85 ), TE (cultivated in the first half with Tifton 85 grass, and in the second half with elephant grass).

* Means followed by the same lowercase letter, vertical, and upper case, horizontal, do not differ statistically by the Tukey test, at a level of $5 \%$ significance.

The $\mathrm{pH}$ values in the effluents were between 6.2 and 6.7. Matos et al. (2012) found mean values of $\mathrm{pH}$ between 6.6 and 6.9, evaluating $\mathrm{HSSF}-\mathrm{CW}_{\mathrm{S}}$ filled with gravel and cultivated with Tifton 85 grass and elephant grass, in the treatment of MTWW (pH affluent of 3.7 to 4.9). The different crop combinations influenced the $\mathrm{pH}$ values of the effluent only in the CWs-P, being the highest values obtained in the CWs-PWV. The release of acids by plants (Pavinato \& Rosolem, 2008), with the purpose of mineralizing organic compounds, and the greater removal of nutrients by plants, reducing to a lesser magnitude of the $\mathrm{H}^{+}$ion activity, may explain the fact that $\mathrm{pH}$ was higher in the outflow of non-vegetated $\mathrm{CW}_{\mathrm{S}}$ (Matos, 2015). Regarding the different media, the mean $\mathrm{pH}$ values were higher in the CWs-G in all crop combinations. As described by Fia et al. (2010), the release of some cations from the gravel material used as support material resulted in a decrease in the activity of the $\mathrm{H}^{+}$ions in the medium, an unexpected reaction in a chemically inert carrier medium (PET bottle). This justifies, in part, the differences obtained in the effluent $\mathrm{pH}$ values of the HSSF-CWs filled with the different support materials.

The average efficiency of the removal of EC showed significant differences for different support media, and the gravel provided higher effluent values (mean negative efficiencies of greater absolute value) than those obtained in CWs-P. On the other hand, the different crop combinations had no effect on the average efficiency in EC removal from MTWW. This evidence corroborates the hypothesis of release of ions in solution in a medium containing gravel, which also influenced the $\mathrm{pH}$ variable. As discussed, gneissic gravel can release ions into the system, as described by Fia et al. (2010), which is no longer expected in the carrier material made up of PET bottles, since they are chemically inert materials.

The mean values of turbidity in the effluent and the efficiency in its removal varied, respectively, from 11 to 30 NTU and 78 to 91\%. Colares \& Sandri (2013) evaluated the efficiency of HSSF-CWs cultivated with Typha $s p$ and obtained turbidity removal efficiency of $66.8 \%$, when the support medium was natural gravel, $72 \%$ with gravel \# 2 and $71 \%$ when washed gravel was used.
There was a statistical difference between treatments in turbidity removal, with the best results obtained in CWs-P (filled with PET bottles). According to Fia et al. (2010), gravel, as a chemically reactive material, wears out over time with release of solids in wastewater under treatment, which explains the higher efficiencies in CWs-P in this variable. In addition, the higher HRT, Table 1 , in the CWs-P, may have provided greater solids removal, since lower velocity in the medium allows for greater sedimentation of solids in the treated wastewater, which would also explain the best results achieved in the filled with PET bottles.

The mean values of the concentration of $\mathrm{BOD}_{5}$ in the effluent and of the efficiencies in its removal varied, respectively, from 60 to $85 \mathrm{mg} \mathrm{L}^{-1}$ and from 82 to $87 \%$, while those of COD were between 64 to $133 \mathrm{mg} \mathrm{L}^{-1}$ and 88 to $93 \%$. Chagas et al. (2013), used gravel \#0 in HSSF-CW cultivated in yellow-lily (HRT of 3.9 days), obtaining $90.1 \%$ efficiency in the removal of $\mathrm{BOD}_{5}$ sanitary sewage and Çakir et al. (2015) evaluating the performance of HSSF-CWs cultivated with reeds, in the treatment of domestic sewage, obtained removal efficiencies of 49.1 and $64.9 \%$ of BOD. Matos et al. (2012), evaluating HSSFCWs used in the treatment of MTWW, with OLRs between 66 and $570 \mathrm{~kg} \mathrm{ha}^{-1} \mathrm{~d}^{-1} \mathrm{BOD}_{5}$, HRT of 4.8 days, cultivated with Tifton 85 grass and elephant grass, obtained efficiencies in the removal of $\mathrm{BOD}_{5}$ in the range of 79 to $96 \%$.

Akratos \& Tsihrintzis (2007), evaluating HSSFCWs cultivated with cattail, filled with gneissic gravel \# 0 , obtained efficiencies in the removal of $\mathrm{BOD}_{5}$ of $88 \%$, $94 \%, 91 \%$ and $90 \%$, with HRT of $6,8,14$ and 20 days, respectively, and suggested that the higher the HRT the greater the removal capacity of $\mathrm{BOD}_{5}$ of wastewater under treatment in CWs. However, in this study, the different HRT in CWs-G and $\mathrm{CW}_{\mathrm{S}} \mathrm{P}$ did not influence the efficiency in the $\mathrm{BOD}_{5}$ removal, since there was no significant difference in the efficiency in the $\mathrm{BOD}_{5}$ removal.

When comparing different crop combinations, combinations WV (no vegetation) and ET (elephant grass followed by Tifton 85) provided COD removals higher than those obtained by TE combination (Tifton 85 grass 
and elephant, in sequence), which are assumed to be associated with the root type of the cultivated plant species. Tifton 85 grass has a deeper root, with vertical growth, and elephant grass, the shortest and most superficial root, presenting horizontal growth (Matos et al., 2010a). Thus, it is speculated that when Tifton 85 grass was cultivated in the second half of the CWs, it provided the formation of a more efficient physical barrier in the removal of the particulate organic matter, also reducing the passage of solids released by the plant itself. In these conditions, it would also justify the reason why the $\mathrm{CW}_{\mathrm{S}}$ without vegetation (absence of vegetal debris) is as efficient as the $\mathrm{CW}_{\mathrm{S}}$ with ET.

The mean values of TS concentration in the effluent and efficiency in its removal were respectively between 186 to $287 \mathrm{mg} \mathrm{L}^{-1}$ and 52 to $70 \%$ and, of TSS, of 9 to 38 $\mathrm{mg} \mathrm{L}^{-1}$ and 82 to $96 \%$. The crushed PET bottles provided mean efficiencies higher than those obtained by the gravel support medium, which can be explained by the wear suffered by the gravel and the higher HRT in the CWs-P, as already explained for the variable turbidity.

Corroborating with the observed trend for COD removal, the mean efficiencies in TS and TSS removal in the WV and ET crop combinations were higher than those obtained in the TE combination, which, however, were equal to each other. Thus, the hypothesis of the importance of filtration in the root environment is reinforced.

The mean concentrations of Total-P in the effluent and the efficiency in its removal varied, respectively, from 8 to $9 \mathrm{mg} \mathrm{L}^{-1}$ and 20 to $29 \%$. The different media and crop combination of the treatments did not interfere in the removal of Total-P. Mendonça et al. (2012) verified that there was no significant difference between the cultivated and non-cultivated HSSF-CWs in the removal of phosphorus, with average efficiencies varying from 19 to 34\%. Amorim et al. (2015), worked with loading rates of $\mathrm{P}$ higher than those evaluated in this study, between 13 and $240 \mathrm{~kg} \mathrm{ha}^{-1} \mathrm{~d}^{-1}$, obtained efficiency in the removal of $\mathrm{P}$, which varied between 20 and $30 \%$.

There are no limits of phosphorus concentration in effluents to be released in water bodies, in the Brazilian environmental legislation, therefore, there is nothing to compare in relation to this. But it can be said that HSSFCWs, in general, presented satisfactory removal efficiencies of $\mathrm{P}$ from MTWW, when comparing the values to those obtained in other processes and systems used in the treatment of wastewater.

In the effluent the mean values of Total-N concentration and efficiency in their removal varied, respectively, from 15 to $23 \mathrm{mg} \mathrm{L}^{-1}$ and from 21 to $50 \%$. CWs-G provided higher mean efficiencies in Total-N removal than the CWs-P.

Higher $\mathrm{N}$ concentrations in the dry matter of the aerial part of the grasses and nitrogen extraction capacity via aerial part were obtained in the CWs filled with gravel, which is an indication of the possibility of obtaining better efficiencies in the removal of $\mathrm{N}$ from MTWW in these systems. Another plausible explanation is that the lower porosity of the $\mathrm{CW}_{\mathrm{S}}-\mathrm{G}$ has provided less redox potential, and possible greater denitrification, compared to the PETfilled bed.

The ET crop combination presented an average higher than those obtained in the WV and TE combinations. This result can be explained by the differences between the roots of the plant species, as already explained for the differences obtained in the crop combination in the removal of COD. This time, the planted unit differed from the uncultivated bed, due to the presence of plant species contributing to nutrient extraction.

In view of this, it is clear the importance of the correct choice of plant species and, in the case of polyculture, the positioning of cultivation within the system. More resistant species, superficial roots, with greater capacity of insertion of oxygen in the bed (through structures like aerenchyma) and more resistant to high organic loads, should be cultivated in the initial part of the CWs, being a predominantly anaerobic zone. Already species with greater need of nutrients, should be positioned after the region of more intense organic matter removal, being able to associate other species for reduction of coliforms, for example. Some studies have shown this positive relationship between plant diversity and the system's ability to remove pollutants, such as those conducted by Kouki et al. (2012); Turkera et al. (2013) and Wang et al. (2014b).

According to the literature review by Vymazal (2007), the mean efficiencies in nitrogen removals are between 40 and $55 \%$, when loads of 6.8 and $17 \mathrm{~kg} \mathrm{ha}^{-1} \mathrm{~d}^{-1}$ are applied of $\mathrm{N}$ in different configurations of constructed wetlands systems, vertical and horizontal. Thus, having an average load of $20 \mathrm{~kg} \mathrm{ha}^{-1} \mathrm{~d}^{-1}$ of $\mathrm{N}$, with removals varying from 21 to $50 \%$, the results were close to those commonly found.

The mean values of $\mathrm{K}$ concentration in the effluent and removal efficiency varied, respectively, from 9 to 11 $\mathrm{mg} \mathrm{L}^{-1}$ and of 7 to $23 \%$ and; to $\mathrm{Na}$, the values, in the same sequence, ranged from 12 to $15 \mathrm{mg} \mathrm{L}^{-1}$ and -14 to $8 \%$ $\left(\mathrm{CW}_{\mathrm{S}}-\mathrm{PET}\right)$.

Matos et al. (2010b) treating swine wastewater (SWW) in HSSF-CWs cultivated with alternanthera, cattail and Tifton 85 grass and in uncultivated $\mathrm{CW}_{\mathrm{S}}$, which received loads of $36.3 \mathrm{~kg} \mathrm{ha}^{-1} \mathrm{~d}^{-1}$ of $\mathrm{K}$ and $11.3 \mathrm{~kg} \mathrm{ha}^{-1} \mathrm{~d}^{-1}$ of $\mathrm{Na}$, resulted in removal efficiencies of $\mathrm{K}$ between 29 and $46 \%$ and $\mathrm{Na}$ between 18 and $28 \%$, values higher than those obtained in this study. Fia et al. (2015) obtained efficiencies in the removal of 15 to $27 \%$ of $\mathrm{K}$ and 2 to $24 \%$ of $\mathrm{Na}$ in the treatment of swine wastewater (SWW) in HSSF-CWs cultivated with cattail and Tifton 85 grass, when applying loads between 21 to $80 \mathrm{~kg} \mathrm{ha}^{-1} \mathrm{~d}^{-1}$ of $\mathrm{K}$ and 15 to $56 \mathrm{~kg} \mathrm{ha}^{-1} \mathrm{~d}^{-1}$ of $\mathrm{Na}$. It is observed, that there are species with greater potential of removal of certain nutrients.

Fia et al. (2015) studied the influence of nutrient load and cultivated species on the removal of $\mathrm{K}, \mathrm{Na}, \mathrm{Cu}$ and $\mathrm{Zn}$ in the treatment of swine wastewater (SWW) in HSSF-CWs cultivated with cattail and Tifton 85 grass, and verified that greater removal of this element was obtained in treatments which received lower loads, corroborating what was observed in this study.

Different support materials and cultivation combinations did not influence the removal of K. Already, in the $\mathrm{Na}$ removal, the support medium consisting of crushed PET bottles provided mean efficiencies higher than those obtained by the gravel support medium and the different vegetal combinations did not influence the removal of this variable.

It is observed that the efficiencies provided by the evaluated treatments were low, in relation to the studies 
demonstrated. However, the applied load should be taken into account, which was higher than those that generated the best results, the HRT and the evaluated cultures. Since $\mathrm{Na}$ and $\mathrm{K}$ are highly soluble in water, there is the possibility of adsorption to the carrier medium, until saturation or incorporation into the biofilm occurs. However, given the great mobility, the absorption seems to be the most sensitive factor to the change in the concentration of chemical elements in the effluent.

Finally, it is interesting to use PET bottles as a support medium in $\mathrm{HSSF}-\mathrm{CW}_{\mathrm{S}}$, providing efficiencies similar to that beds filled with gravel, and with less risk of wear over the operating time, which could generate solids of clogging.

\section{CONCLUSIONS}

The substrate composed of crushed PET bottles was as efficient as gravel in the removal of some variables $\left(\mathrm{BOD}_{5}, \mathrm{COD}\right.$, Total-P and Total-K) being, in some situations, even more effective (turbidity, TS, TSS and $\mathrm{Na}$ ). Gravel, on the other hand, provided greater removals of Total-N from MTWW.

In the HSSF-CWs without culture and those cultivated with elephant grass in its first half and Tifton 85 grass in its second half, there were higher mean efficiencies in COD and TSS removals, and in the latter, higher mean removal of Total-N. Thus, the use of PET bottles as a support medium has shown promising, and that the choice and disposal of plant species can provide gain in removal efficiency.

\section{ACKNOWLEDGMENTS}

We would like to thank FAPEMIG, for the financial support that allowed the development of this project and granting the scholarship, to EPAMIG and the Institute of Dairy Products Cândido Tostes for the opportunity granted and the Federal University of Viçosa and to the Department of Agricultural Engineering for the support and infrastructure.

\section{REFERENCES}

Akratos CS, Tsihrintzis VA (2007) Effect of temperature, HRT, vegetation and porous media on removal efficiency of pilot-scale horizontal subsurface flow constructed wetlands. Ecological Engineering 29:173-191.

Amorim F, Fia R, Silva JRM, Chaves CFM, Pasqualin PP (2015) Unidades combinadas RAFA-SAC para tratamento de água residuária de suinocultura: Parte II Nutrientes. Engenharia Agrícola 35(5):931-940.

APHA - American Public Health Association, AWWA American Water Works Association, WEF - Water Environment Federation (2012) Standard methods for the examination of water and wastewater. Washington, $22^{\text {nd }}$ ed. 1496p.

Avelar FF, Matos AT, Leite Junior AR, Portes MR, Gualhano DS (2015) Desempenho agronômico de mentha aquática cultivada em sistemas alagados construídos sob diferentes taxas de aplicação orgânica. Engenharia Agrícola 35(2):322-330.
Borges AC, Zaparoli BR, Matos AT, Miranda ST, Moreira AR, Ranieri E (2015) Potential for denitrification in sequencing batch constructed wetlands cultivated with $\mathrm{T}$. latifolia and C. zizanioides. Desalination and Water Treatment 57(12):1-9.

Çakir R, Gidirislioglu A, Çebi U (2015) A study on the effects of different hydraulic loading rates (HLR) on pollutant removal efficiency of subsurface horizontal-flow constructed wetlands used for treatment of domestic wastewaters. Journal of Environmental Management 164:121-128.

Calheiros CSC, Bessa VS, Mesquita RBR, Brix H, Rangel AOSS, Castro PML (2015) Constructed wetland with a polyculture of ornamental plants for wastewater treatment at a rural tourism facility. Ecological Engineering 79:1-7.

Chagas RCC, Matos AT, Cecon PR, Lo Monaco PAV, Pimenta LA (2013) Tratamento de esgoto sanitário em sistemas alagados construídos cultivados com LírioAmarelo. Revista Engenharia Agrícola 33(6):1144-1155.

Chang J-J, Wu S-Q, Dai Y-R, Liang W, Wu Z-B (2012) Treatment performance of integrated vertical-flow constructed wetland plots for domestic wastewater. Ecological Engineering 44:152-159.

Colares CJG, Sandri D (2013) Eficiência do tratamento de esgoto com tanques sépticos seguidos de leitos cultivados com diferentes meios de suporte. Ambi-Agua 8(1):172185.

Dordio AV, Carvalho AJP (2013) Organic xenobiotics removal in constructed wetlands, with emphasis on the importance of the support matrix. Journal of Hazardous Materials 252-253:272-292.

Ferres GC, Matos AT, Martinez MA, Borges AC, Matos MP (2017) Variabilidade na condutividade hidráulica em sistemas alagados construídos de escoamento horizontal subsuperficial. Revista Engenharia Agrícola 37(2).

Fia RL, Matos AT, Fia R, Borges AC, Abreu EC (2015) Influência de carga de nutrientes e de espécie cultivada na remoção de $\mathrm{K}, \mathrm{Na}$, Cu e $\mathrm{Zn}$ da água residuária da suinocultura tratada em sistema alagados construídos. Revista Ambi-Água 10(3):542-553.

Fia R, Matos AT, Fia FRL, Matos MP, Lambert TF, Nascimento FS (2010) Desempenho de forrageiras em sistemas alagados de tratamento de águas residuárias do processamento do café. Revista Brasileira de Engenharia Agrícola e Ambiental 14(8):842-847.

Kantawanichkul S, Wannasri S (2013) Wastewater treatment performances of horizontal and vertical subsurface flow constructed wetland systems in tropical climate. Songklanakarin Journal of Science and Technology 35(5):599-603.

Kouki S, Saidi N, Rajeb AB, M'hiri F (2012) Potential of a polyculture of Arundo donax and Typha latifolia for growth and phytotreatment of wastewater pollution. African Journal of Biotechnology 11(87):15341-15352.

Matos AT, Abrahão SS, Borges AC, Matos MP (2010a) Influência da taxa de carga orgânica no desempenho de sistemas alagados construídos cultivados com forrageiras. Revista Engenharia Sanitária e Ambiental 15(1):83-92. 
Matos AT, Freitas WS, Lo Monaco PAV (2010b)

Eficiência de sistemas alagados construídos na remoção de poluentes de águas residuárias da suinocultura. Revista Ambiente e Água 5(2):119-132.

Matos AT, Abrahão SS, Lo Monaco PAV (2012) Eficiência de sistemas alagados construídos na remoção de poluentes de águas residuárias de indústria de laticínios. Engenharia Agrícola 32(6):1144-1155.

Matos AT (2015) Manual de análise de resíduos sólidos e águas residuárias. Viçosa, Editora UFV, 149p.

Melo ADS, Reis RP (2007) Tanques de expansão e resfriamento de leite como alternativa de desenvolvimento regional para produtores familiares. Organizações Rurais e Agroindustriais 9(1).

Mendonça HV, Ribeiro CBM, Borges AC, Bastos RR (2012) Remoção de nitrogênio e fósforo de águas residuárias de laticínios por sistemas alagados construídos operando em bateladas. Ambi-Água 7(2):75-87.

Mendonça HV, Ribeiro CBM, Borges AC, Bastos RR (2015) Sistemas Alagados Construídos em Batelada: remoção de Demanda Bioquímica de Oxigênio e regulação de $\mathrm{pH}$ no tratamento de efluentes de laticínios. Ambi-Água 10(2):442-453.

PAVINATO, P.S.; ROSOLEM, C.A. Disponibilidade de nutrientes no solo - Decomposição e liberação de compostos orgânicos de resíduos vegetais. Revista Bras. Ci. Solo, v.32, p.911-920, 2008.

Pedescoll A, Uggetti E, Llorens E, Granés F, Garcia D, Garcia J (2009) Practical method based on saturated hydraulic conductivity used to assess clogging in subsurface flow constructed wetlands. Ecological Engineering 35:1216-1224.

Prata RCC, Matos AT, Cecon PR, Lo Monaco PAV, Pimenta LA (2013) Tratamento de esgoto sanitário em sistemas alagados construídos cultivados com lírioamarelo. Engenharia Agrícola 33(6):1144-1155.

Rousso BZ, Pelissari C, Sezerino PH (2015) Desempenho de um wetland construído horizontal empregado no tratamento de esgoto doméstico ao longo de 20 anos de operação. In: Simpósio Brasileiro sobre Wetlands Construídos, Curitiba, Anais...
Saeed T, Sun G (2013) A lab-scale study of constructed wetlands with sugarcane bagasse and sand media for the treatment of textile wastewater. Bioresource technology 128:438-447.

Sarmento AP, Borges AC, Matos AT (2012) Evaluation of Vertical-Flow Constructed Wetlands for Swine Wastewater Treatment. Water, Air and Soil Pollution 223:1065-1071.

Turkera OC, Bocukb H, Yakarb A (2013) The phytoremediation ability of a polyculture constructed wetland to treat boron from mine effluent. Journal of Hazardous Materials (252-253):132-141.

Vymazal J (2007) Removal of nutrients in various types of constructed wetlands. Science of the Total Environment (380):48-65.

Wang H, Huang CC, Ge Y, Wu JZ, Chang J (2014b) The Performance of Species Mixtures in Nitrogen and Phosphorus Removal at Different Hydraulic Retention Times. Polish Journal of Environmental Studies 23(3):922.

Wang Y, Song X, Liao W, Niu R, Wang W, Ding Y, Wang Y (2014a) Impacts of inlet-outlet configuration, flow rate and filter size on hydraulic behavior of quasi-2dimensional horizontal constructed wetland.: $\mathrm{NaCl}$ and dye tracer test. Ecological Engineering 69:177-185.

Zacarkim CE, Oliveira LC, Welter RA, Szymanki N, Quiñones FR, Palácio SM, Damasceno S (2014) Analysis of a Wetland System In The Post-Treatment of Wastewater. Revista Brasileira de Energias Renováveis 3(1).

Zhang DQ, Gersberg RM, Ng WJ, Tan SK (2014) Removal of pharmaceuticals and personal care products in aquatic plant-based systems: a review. Environmental Pollution 184:620-639. 